\title{
Ekstraksi dan Uji Stabilitas Zat Warna Alami dari Biji Buah Pinang (Areca catechu L.) sebagai Bahan Pengganti Pewarna Sintetik pada Produk Minuman
}

\section{[Extraction and Stability Test of Natural Dyes from Areca catechu L. as a Substitute for Synthetic Dyes in Beverage Products]}

\author{
St. Chadijah, Sari Ningsih, Ummi Zahra*, Syarifah Rabiatul Adawiah, lin Novianty \\ Jurusan Kimia, UIN Alauddin Makassar
}

\begin{abstract}
Natural dyes are an alternative dye that is not toxic, environmentally, friendly and easily degraded. Therefore, optimizing the use of body coloring sources is carried out. One of the natural dyes released is tannin from betel nuts. Tannins are polar pigments. This study aims to determine the results of natural dyes in betel nuts and find out the durability produced and known organoleptic results. Dyestuff extraction from betel nuts was carried out with $96 \%$ ethanol. Testing the color stability of betel nut seedlings was carried out on the effect of $\mathrm{pH}$, temperature and storage time with the method UV-Vis Spectrophotometer. Then the application of betel nut dyes on beverage products was carried out. The results showed that betel fruit produced tannin dyes in brownish red color with an average tannin content of $28.002 \mathrm{mg} / \mathrm{L}$. Dyes stabilized at $\mathrm{pH}$ of 6 by heating at $40^{\circ} \mathrm{C}$ and storage for 2 days. The results of organoleptic tests showed that the extract of areca nut powder can be used as a natural dye in beverage products with a level of color, smell and flavor that emits at a concentration of $0.005 \mathrm{~g} / \mathrm{mL}$ of dyes.
\end{abstract}

Keywords: Extraction, tannin, areca nuts, color stability, organoleptic

Abstrak. Pewarna alami merupakan alternatif pewarna yang tidak toksik, ramah lingkungan dan mudah terdegradasi. Oleh sebab itu, optimalisasi penggunaan sumber pewarna alami penting dilakukan. Salah satu zat pewarna alami yang berpotensi adalah tanin dari biji buah pinang. Penelitian ini bertujuan untuk mengetahui golongan zat warna alami yang terdapat pada biji buah pinang, stabilitas warna yang dihasilkan dan melakukan uji organoleptik. Ekstraksi zat warna dari biji buah pinang dilakukan dengan pelarut etanol $96 \%$. Pengujian stabilitas warna tanin biji buah pinang dilakukan terhadap pengaruh $\mathrm{pH}$, suhu dan lama penyimpanan menggunakan Spektrofotometer UV-Vis. Pengaplikasian zat warna biji buah pinang dilakukan pada produk minuman. Hasil penelitian menunjukkan bahwa biji buah pinang menghasilkan zat warna tanin merah kecokelatan dengan ratarata kadar tanin sebesar $28,002 \mathrm{mg} / \mathrm{L}$. Pewarna stabil pada kondisi $\mathrm{pH} 6$, pemanasan suhu $40^{\circ} \mathrm{C}$ dan penyimpanan selama 2 hari. Hasil uji organoleptik menunjukkan bahwa bubuk ekstrak biji buah pinang dapat digunakan sebagai pewarna alami pada produk minuman dengan tingkat warna, aroma dan rasa yang disukai pada konsentrasi 0,005 $\mathrm{g} / \mathrm{mL}$ pewarna.

Kata kunci: Ekstraksi, tanin, biji buah pinang, stabilitas warna, organoleptik.

Diterima: 17 Juni 2021, Disetujui: 21 Agustus 2021

Sitasi: Chadijah, St., Ningsih, S., Zahra, U., Adawiah, SR., dan Novianty, I. (2021). Ekstraksi dan Uji Stabilitas Zat Warna Alami dari Biji Buah Pinang (Areca catechu L.) sebagai Bahan Pengganti Pewarna Sintetik pada Produk Minuman. KOVALEN: Jurnal Riset Kimia, $7(2): 137-145$.

\footnotetext{
* Corresponding author

E-mail: ummi.zahra@uin-alauddin.ac.id
} 


\section{LATAR BELAKANG}

Penggunaan zat warna pada produk merupakan hal penting untuk menambah nilai jual produk. Zat warna merupakan salah satu faktor yang menjadi pertimbangan konsumen dalam menilai baik buruknya kriteria suatu produk makanan ataupun minuman. Penambahan zat warna dalam produk pangan bertujuan memberikan penampilan yang menarik sesuai keinginan konsumen, memperkuat warna alami yang sudah ada dan mencegah hilangnya zat warna yang disebabkan oleh paparan sinar matahari, suhu yang ekstrim, kelembaban dan kondisi penyimpanan (Nurandriea \& Azmi, 2017).

Berdasarkan asalnya zat warna terdiri dari dua jenis yaitu pewarna alami dan pewarna sintentik. Pewarna alami berasal dari tumbuhan ataupun hewan sedangkan pewarna sintetik terbuat dari campuran bahan-bahan kimia. Pewarna alami dapat terbentuk dari proses pemanasan, penyimpanan dan pengolahan. Pembuatan pewarna sintesis ini biasanya ditambahkan asam sulfat atau asam nitrat yang seringkali terkontaminasi dengan logam berat yang bersifat racun.

Zat warna sintetik lebih disukai oleh produsen karena lebih mudah diperoleh, harga terjangkau, memiliki warna yang stabil, jenis warna bermacam-macam dan lebih praktis dalam penggunaannya (Suarsa et al., 2011). Namun demikian, bahaya penggunaan jangka panjang zat warna sintetik menjadi kekhawatiran tersendiri bagi para konsumen. Selain itu, penyalahgunaan pewarna sintetik non pangan seperti pewarna tekstil yang diaplikasikan untuk bahan pangan dapat menyebabkan resiko terhadap kesehatan. Pewarna sintetik yang sering disalahgunakan dalam industri makanan atau minuman yaitu
Rhodamin B. Rhodamin B ini merupakan bahan yang sangat berbahaya, karena dapat memicu terjadinya kanker (Pujilestari, 2015).

Oleh karena itu, pencarian pewarna alami dari tumbuhan yang aman bagi konsumen dan dapat digunakan untuk mewarnai makanan atau minuman terus dilakukan. Keunggulan pewarna alami terus diteliti karena selain ramah lingkungan, penggunaan zat pewarna alami dalam industri tekstil memiliki potensi pasar yang tinggi sebagai komoditas unggulan produk Indonesia dengan daya tarik pada karakteristik yang unik, etnik, dan eksklusif sehingga membuat nilai jualnya menjadi lebih tinggi (Azizah \& Hartana, 2018). Salah satu sumber bahan alami yang memiliki potensi di Indonesia dan dapat dimanfaatkan sebagai pewarna alami adalah biji buah pinang (Wulansari et al., 2012). Penelitian ini bertujuan untuk mengetahui golongan zat warna alami pada biji buah pinang dan stabilitas warna yang dihasilkan serta melakukan uji organoleptik

\section{METODE PENELITIAN}

\section{Bahan dan Peralatan}

Bahan-bahan yang digunakan dalam penelitian ini yaitu aquabidest $\left(\mathrm{H}_{2} \mathrm{O}\right)$, asam klorida $(\mathrm{HCl}) 2 \mathrm{M}$, asam tanat $\left(\mathrm{C}_{76} \mathrm{H}_{52} \mathrm{O}_{46}\right)$, biji buah pinang (Areca catechu L.), buffer asam sitrat $\left(\mathrm{C}_{6} \mathrm{H}_{8} \mathrm{O}_{7}\right.$ ) (dalam pH 4 dan 6), buffer $\mathrm{KCl}$ $\mathrm{HCl}(\mathrm{pH} 2)$, etanol $\left(\mathrm{C}_{2} \mathrm{H}_{5} \mathrm{OH}\right) 96 \%$, gula pasir, kertas lakmus, kertas saring, natrium hidroksida $(\mathrm{NaOH}) 2 \mathrm{M}$, natrium karbonat $\left(\mathrm{Na}_{2} \mathrm{CO}_{3}\right)$ jenuh, natrium klorida $(\mathrm{NaCl})$, pereaksi besi(III) klorida $\left(\mathrm{FeCl}_{3}\right)$, pereaksi folin denis, pereaksi Mayer, pereaksi Wagner.

Peralatan yang digunakan yaitu Spekrofotometer UV-Vis Varian Cary 50 cone, freeze drying merk Scanvac, rotary evaporator, inkubator, tanur, oven, neraca analitik, blender, 
termometer $1000^{\circ} \mathrm{C}$, pipet skala $10 \mathrm{~mL}, 5 \mathrm{~mL}$ dan $1 \mathrm{~mL}$, alat-alat gelas, cawan porselin, bulp, pisau, toples, pipet tetes, batang pengaduk, corong dan botol semprot.

\section{Prosedur Penelitian}

\section{Penyiapan Bahan}

Sampel yang digunakan yaitu biji buah pinang muda yang diperoleh dari desa Sumber Makmur, kec. Kalaena, kab. Luwu Timur, Sulawesi Selatan. Buah pinang muda. dibersihkan, dipotong-potong, dikeringkan pada suhu ruang dan, dihaluskan menggunakan blender (Sulastry, 2009).

Serbuk biji buah pinang ditimbang $1 \mathrm{Kg}$ kemudian dimaserasi menggunakan etanol $96 \%$ selama $3 \times 24$ jam. Fitrat hasil maserasi pertama, kedua dan ketiga diuapkan dengan rotary evaporator kemudian dikeringkan menggunakan pengering beku (freeze drying) pada suhu $-40^{\circ} \mathrm{C}$ (Haryadi, 2013: 55) hingga menjadi serbuk.

\section{Uji Kualitatif Senyawa Fitokimia}

a. Uji tanin (Arifah et al., 2016)

Serbuk ditambahkan 3 tetes pereaksi $\mathrm{FeCl}_{3}$. Apabila terjadi perubahan warna menjadi hijau atau biru kehitaman maka mengandung tanin.

b. Uji alkaloid (Marliana et al., 2005)

Serbuk sebanyak 0,1 gram dimasukkan ke dalam cawan porselin, ditambahkan $3 \mathrm{~mL} \mathrm{HCl}$ $2 \mathrm{M}$, diaduk dan dinginkan pada suhu ruang. Kemudian ditambahkan 0,3 g NaCl diaduk dan disaring. Selanjutnya filtrat ditambahkan 2 tetes $\mathrm{HCl} 2 \mathrm{M}$ dan dipisahkan menjadi dua bagian $\mathrm{A}$ dan B. Bagian A diuji dengan pereaksi Mayer dan bagian $B$ diuji dengan pereaksi Wagner. Apabila terbentuk endapan putih dan coklat maka positif mengandung alkaloid. c. Uji saponin (Marliana et al., 2005)

Serbuk sebanyak 0,1gram dimasukkan ke dalam tabung reaksi dan ditambahkan $10 \mathrm{~mL}$ aquades. Kemudian dikocok selama 30 detik dan apabila terdapat busa yang bertahan selama 30 detik maka positif mengandung saponin.

d. Uji antosianin (Neliyanti \& Idiawati, 2014)

Serbuk sebanyak 0,1gram ditambahkan $\mathrm{HCl} 2 \mathrm{M}$ kemudian dipanaskan selama 5 menit pada suhu $100^{\circ} \mathrm{C}$. Apabila timbul warna merah maka mengandung antosianin.

\section{Uji Kuantitatif Kadar Tanin (Mukhriani et al., 2014)}

a. Pembuatan larutan standar asam tanat 1000 ppm

0,1 gram asam tanat dilarutkan dalam $100 \mathrm{~mL}$ aquabides dan dibuat seri pengenceran 20, 40, 60, 80 dan 100 ppm dari larutan baku 1000 ppm. Kemudian diambil masing-masing 1 $\mathrm{mL}$ dan dimasukkan ke dalam labu ukur $10 \mathrm{~mL}$ yang berisi $7,5 \mathrm{~mL}$ aquabides. Setelah itu ditambahkan $0,5 \mathrm{~mL}$ pereaksi folin denis diamkan selama 3 menit. Selanjutnya ditambahkan dengan $1 \mathrm{~mL}$ larutan $\mathrm{Na}_{2} \mathrm{CO}_{3}$ jenuh dan diinkubasi selama 15 menit. Kemudian diukur absorbansinya pada panjang gelombang $740 \mathrm{~nm}$.

b. Penetapan kadar tanin

$0,1 \mathrm{~g}$ serbuk dilarutkan dengan aquabides sampai $100 \mathrm{~mL}$. Kemudian dipipet 1 $\mathrm{mL}$ ke dalam labu ukur $10 \mathrm{~mL}$ yang telah berisi 7,5 $\mathrm{mL}$ aquabides. Setelah itu ditambahkan 0,5 $\mathrm{mL}$ pereaksi folin denis didiamkan selama 3 menit. Selanjutnya ditambahkan $1 \mathrm{~mL}$ larutan $\mathrm{Na}_{2} \mathrm{CO}_{3}$ jenuh dan diinkubasi selama 15 menit. Kemudian diukur absorbansinya pada panjang gelomban $740 \mathrm{~nm}$. 
Uji Stabilitas (Fauziah et al., 2016)

a. Pengaruh Suhu

Serbuk dilarutkan sebanyak 0,1 gram dalam $50 \mathrm{~mL}$ aquades. Larutan dipanaskan pada suhu 40,60 , dan $80^{\circ} \mathrm{C}$ selama 1 jam. Kemudian diukur absorbansinya pada panjang gelombang maksimum.

b. Pengaruh $\mathrm{pH}$

Stabilitas serbuk dibuat 3 tingkat keasaman $(\mathrm{pH} \mathrm{2,} \mathrm{4,} \mathrm{6).} \mathrm{Rentetan} \mathrm{serbuk}$ sebanyak 0,1 gram dilarutkan dalam $50 \mathrm{~mL}$ buffer asam sitrat sesuai variasi pH. Kemudian diukur absorbansinya pada panjang gelombang maksimum.

\section{c. Pengaruh Lama Penyimpanan}

Serbuk disimpan pada suhu kamar dengan variasi lama penyimpanan 2, 4, dan 7 hari. Kemudian dilakukan pengenceran yaitu serbuk dilarutkan sebanyak 0,1 gram dalam 50 $\mathrm{ml}$ aquades. Kemudian diukur absorbansinya pada panjang gelombang maksimum.

\section{Uji Organoleptik (Mahfud, 2015)}

Uji organoleptik dilakukan terhadap 25 orang panelis menggunakan uji hedonik untuk mengetahui daya terima konsumen terhadap pemanfaatan pewarna alami biji buah pinang dalam produk minuman. Uji ini dilakukan dengan penambahan pewarna alami sebesar 1 gram, 2 gram dan 3 gram dari setiap $200 \mathrm{~mL}$ air yang ditambahkan gula pasir $1 \frac{11}{2}$ sendok teh. Beberapa aspek organoleptik yang diamati adalah warna, aroma dan rasa.

\section{HASIL DAN PEMBAHASAN}

\section{Ekstrak Biji Buah Pinang}

Penelitian ini menggunakan biji buah pinang (Areca catechu L.), bagian yang berpotensi membawa zat warna. Buah pinang yang digunakan adalah buah pinang yang masih muda karena kadar taninnya lebih tinggi dibandingkan dengan buah yang sudah tua.

Biji buah pinang dikeringkan pada suhu kamar tanpa terkena cahaya matahari untuk mencegah kerusakan metabolit sekunder yang terkandung di dalamnya. Biji buah pinang dikeringkan untuk mengurangi kadar air sehingga tidak mudah rusak atau ditumbuhi jamur. Sampel kemudian dihaluskan menjadi serbuk, hal ini bertujuan agar proses penarikan zat aktif pada saat ekstraksi dengan cara maserasi lebih mudah.

Maserasi dilakukan dengan merendam serbuk biji buah pinang di dalam pelarut etanol 96\% selama $3 \times 24$ jam. Hasil ekstraksi berupa maserat yang berwarna merah kecoklatan yang dilanjutkan dengan evaporasi. Ekstrak kental yang diperoleh dikeringkan hingga menjadi serbuk dengan menggunakan freeze drying atau pengeringan beku. Serbuk yang dihasilkan yaitu sebanyak 195,98 gram dan berwarna merah kecoklatan.

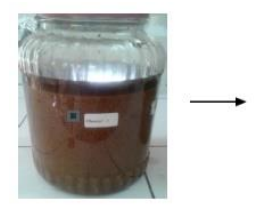

(a)

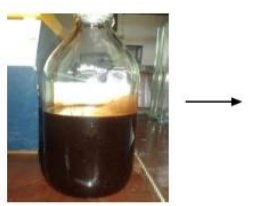

Gambar 1

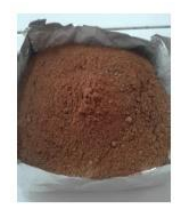

(c)
Keterangan:

(a) Maserasi Serbuk

(b) Ekstrak Kental Etanol

(c) Bubuk Ekstrak Biji Buah Pinang

\section{Senyawa Fitokimia}

\section{Tanin}

Uji tanin menghasilkan warna hijau kehitaman yang menandakan kompleks tannin pada sampel dengan $\mathrm{Fe}$ dari $\mathrm{FeCl}_{3}$. 


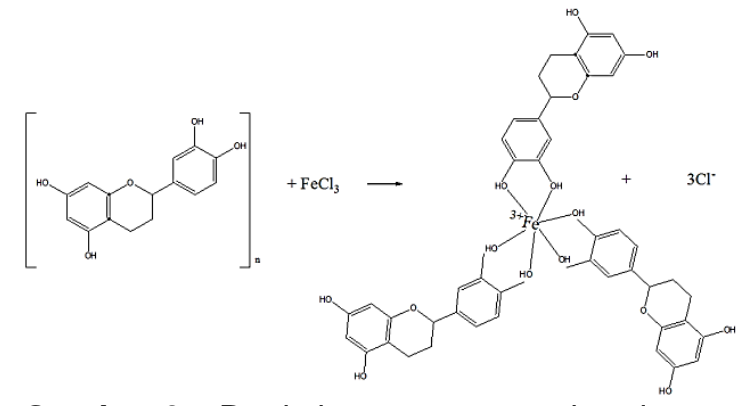

Gambar 2. Reaksi senyawa tanin dengan $\mathrm{FeCl}_{3}$ (Chintya \& Utami, 2017)

\section{Alkaloid}

Uji kualitatif alkaloid menggunakan pereaksi Mayer menunjukkan warna kuning yang menandakan reaksi negatif. Sedangkan hasil untuk pereaksi Wagner diperoleh warna coklat menandakan adanya senyawa alkaloid dalam ekstrak biji buah pinang. Hal ini terjadi karena adanya pengikatan ion $\mathrm{K}^{+}$pada pereaksi wagner dan pada nitrogen pada senyawal alkaloid yang terdapat pada sampel sehingga membentuk warna coklat.

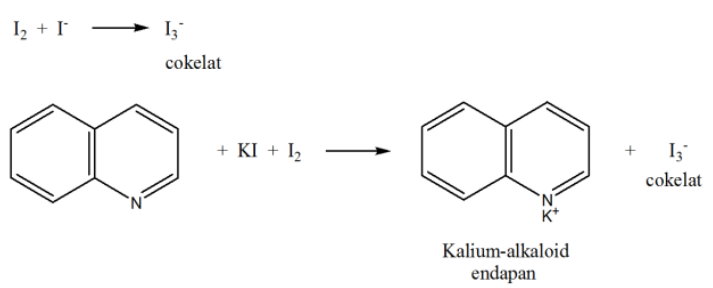

Gambar 3. Reaksi senyawa alkaloid dengan pereaksi wagner (Marliana et al., 2005)

\section{Saponin}

Uji saponin menunjukkan adanya busa dengan pengocokan selama 30 detik. Hasil tersebut menunjukkan adanya saponin dalam ekstrak biji buah pinang. Hal ini terjadi dikarenakan glikosida yang mempunyai kemampuan membentuk buih dalam air yang terhidrolisis menjadi glukosa dan senyawa lainnya.

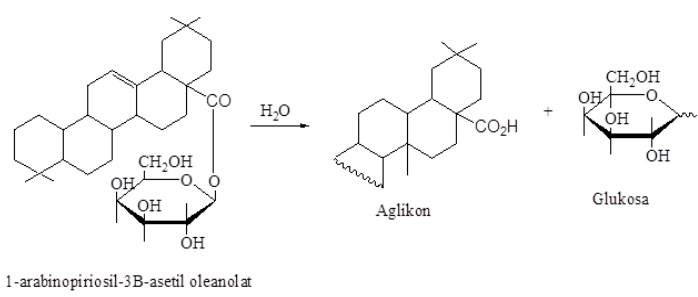

Gambar 4. Reaksi hidrolisis senyawa saponin (Marliana et al., 2005)

\section{Antosianin}

Uji antosianin menunjukkan warna merah yang stabil. Warna yang stabil pada pengujian ini menunjukkan reduksi antosianin menjadi kation flavylium oleh $\mathrm{HCl}$. Pada keadaan ini antosianin berada dalam kondisi paling stabil dan paling berwarna (Seafast, 2012).

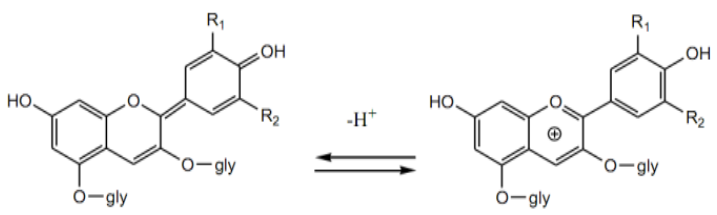

Gambar 5. Struktur antosianin dalam kondisi asam (Giusti \& Wrolstad, 2001)

\section{Kadar Tanin}

Pengujian ini menunjukkan warna biru. Pembentukan warnanya berdasarkan reaksi reduksi oksidasi. Tanin sebagai reduktor dan folin denis sebagai oksidator. Prinsip dari metode folin denis adalah terbentuknya senyawa kompleks berwarna biru yang dapat diukur serapannya pada daerah sinar tampak.

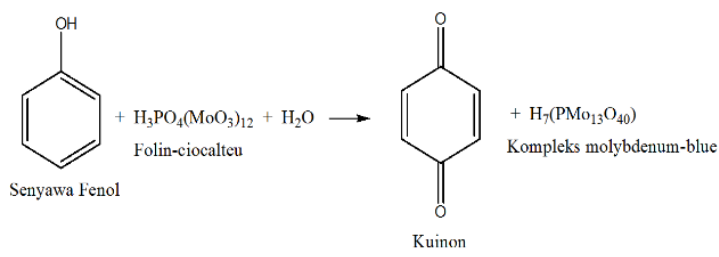

Gambar 6. Reaksi pembentukan senyawa kompleks molybdenum-blue

Hasil pengukuran absorbansi tanin untuk penentuan kurva kalibrasi asam tanat pada panjang gelombang $740 \mathrm{~nm}$ dapat dilihat pada kurva di bawah ini: 


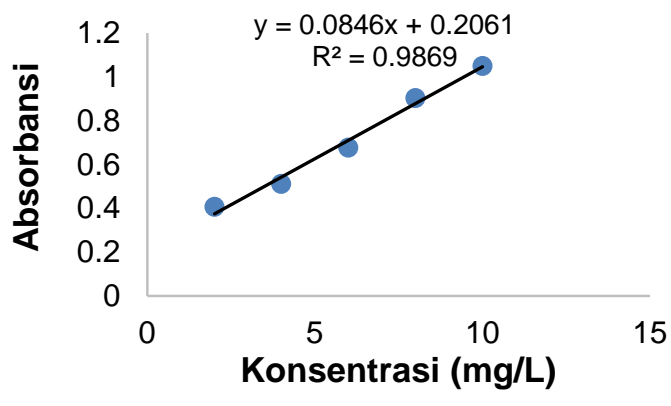

Gambar 7. Kurva standar senyawa tanin

Berdasarkan hasil absorbansi maka diperoleh rata-rata kadar tanin dalam bubuk ekstrak biji buah pinang sebesar 28,002 mg/L.

\section{Stabilitas Zat Warna}

\section{Pengaruh Suhu}

Berdasarkan grafik pada Gambar 8 menunjukkan bahwa semakin tinggi suhu pemanasan maka absorbansi atau stabilitas warna semakin rendah sehingga tingkatan warna (merah) akan berkurang.

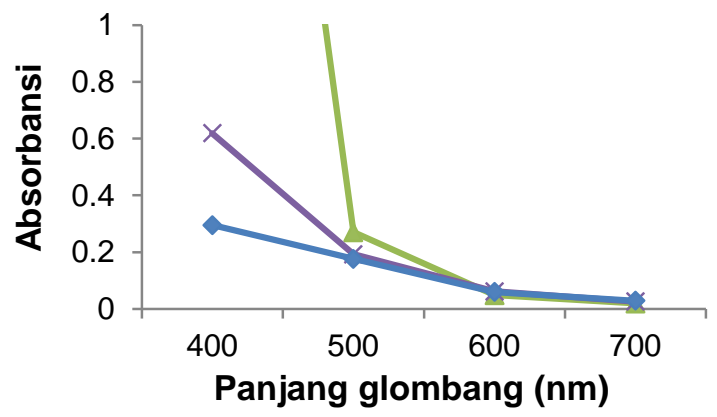

$\longrightarrow$ suhu $40^{\circ} \mathrm{C} \rightleftharpoons$ suhu $60^{\circ} \mathrm{C} \rightleftharpoons$ suhu $80^{\circ} \mathrm{C}$

Gambar 8. Spektrum absorbansi ekstrak biji buah pinang terhadap pengaruh suhu

Zat warna lebih stabil pada suhu $40^{\circ} \mathrm{C}$ dibandingkan pada suhu yang lebih tinggi yaitu $80^{\circ} \mathrm{C}$. Menurut Fauziah et al., (2016) pada suhu tinggi senyawa tanin akan terurai menjadi pyrogallol dan $\mathrm{CO}_{2}$ (Gambar 9).

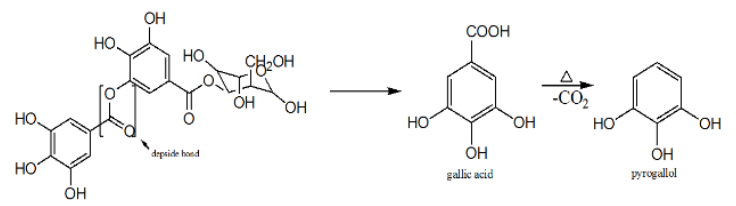

Gambar 9. Reaksi penguraian tanin membentuk pyrogallol dan $\mathrm{CO}_{2}$

\section{Pengaruh $\mathrm{pH}$}

Berdasarkan grafik pada Gambar 10 menunjukkan bahwa nilai absorbansi meningkat hingga $\mathrm{pH} 6$ dan mengalami penurunan pada $\mathrm{pH}$ rendah yaitu dalam keadaan asam. Hal ini menunjukkan bahwa reaksi hidrolisis yang terjadi pada $\mathrm{pH}$ rendah akan menurunkan stabilitas warna tanin, sehingga zat warna lebih stabil pada $\mathrm{pH} 6$ dibandingkan pH 2. Menurut Imelda (2006) senyawa tanin yang dinyatakan dalam bentuk turunannya procyanidin dengan adanya asam akan terhidrolisis menjadi epicatecatkin dan cyaniding sebagaimana reaksinya pada Gambar 11.

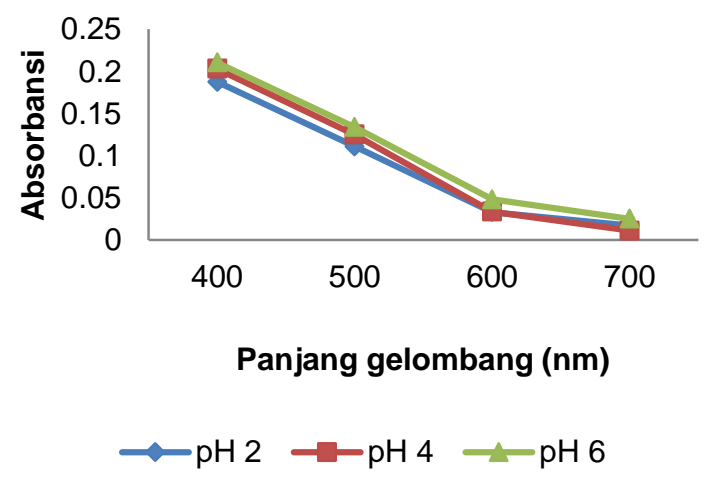

Gambar 10. Spektrum absorbansi ekstrak biji buah pinang terhadap pengaruh $\mathrm{pH}$

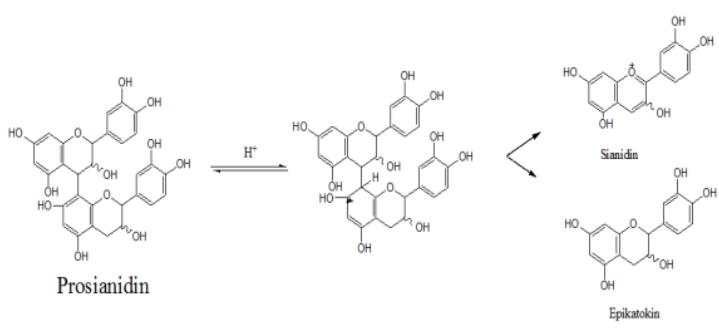

Gambar 11. Reaksi hidrolisis senyawa turunan tanin

\section{Pengaruh lama penyimpanan}

Hasil pengamatan stabilitas warna terhadap pengaruh lama penyimpanan dilakukan selama 2-7 hari. 


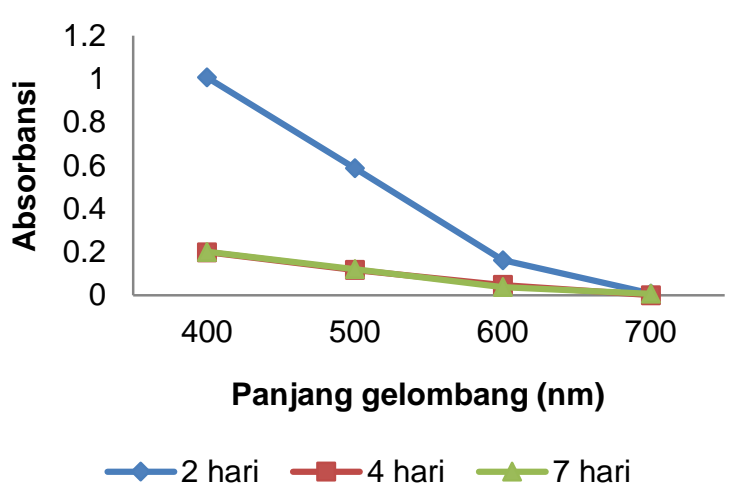

Gambar 12. Spektrum absorbansi ekstrak biji buah pinang terhadap pengaruh lama penyimpanan

Berdasarkan grafik pada Gambar 12 menunjukkan bahwa terjadi penurunan absorbansi pada kenaikkan lama penyimpanan, sehingga penyimpanan lebih stabil pada hari ke-2 dibandingkan hari ke-7. Menurut Fauziah et al., (2016)semakin lama penyimpanan akan menurunkan kestabilan zat warna yang ditandai dengan menurunnya nilai absorbansi. Hal ini dapat terjadi karena disebabkan oleh beberapa faktor seperti oksigen, temperatur dan cahaya. Zat warna jika disimpan terlalu lama memungkinkan terjadinya reaksi oksidasi, sebagaimana berikut ini:

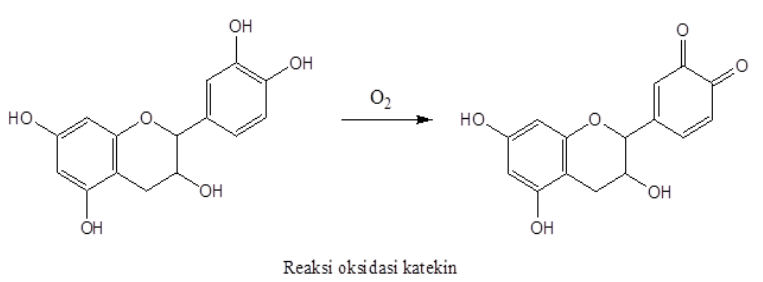

Gambar 13. Reaksi oksidasi katekin

\section{Sifat Organoleptik}

Uji organoleptik atau uji sensori adalah cara pengujian dengan menggunakan alat indra manusia untuk mengukur daya terima suatu produk, sehingga menghasilkan reaksi atau kesan berupa suka atau tidaknya terhadap suatu produk. Pada penelitian ini dilakukan penilaian terhadap warna, aroma dan rasa.
Berdasarkan grafik pada Gambar 14 menunjukkan bahwa dari aspek warna. Dari 25 panelis rata-rata warna yang disukai yaitu pada minuman sirup yang diberi perlakuan dengan penambahan pewarna alami bubuk ekstrak biji buah pinang sebesar 1 gram dan $200 \mathrm{~mL}$ air. Berdasarkan hasil analisis ANOVA yaitu Fhitung > Ftabel dimana Fhitung $=25,40$ dan Ftabel $=3,12$. Dengan demikian HO ditolak artinya adanya perbedaan penambahan konsentrasi pewarna alami bubuk ekstrak biji buah pinang terhadap warna minuman sirup.

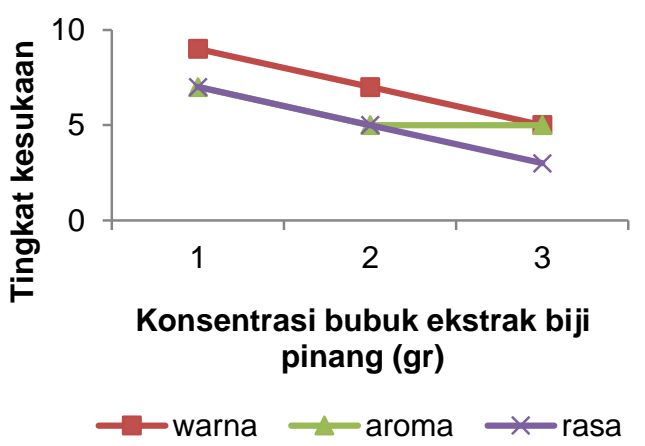

Gambar 14. Hubungan konsentrasi bubuk ekstrak biji pinang terhadap tingkat kesukaan

Aspek aroma menunjukkan dari 25 panelis rata-rata aroma yang disukai yaitu pada minuman sirup yang diberi perlakuan dengan penambahan pewarna alami bubuk ekstrak biji buah pinang sebesar 1 gram dari $200 \mathrm{~mL}$ air. Berdasarkan hasil analisis ANOVA yaitu Fhitung $>$ Ftabel dimana Fhitung $=11,63$ dan Ftabel $=3,12$. Dengan demikian HO ditolak artinya adanya perbedaan penambahan konsentrasi pewarna alami bubuk ekstrak biji buah pinang terhadap aroma minuman sirup.

Aspek rasa menunjukkan dari 25 panelis rata-rata rasa yang disukai yaitu pada minuman sirup yang diberi perlakuan dengan penambahan pewarna alami bubuk ekstrak biji buah pinang sebesar 1 gram dari $200 \mathrm{~mL}$ air. 
Berdasarkan hasil analisis ANOVA yaitu Fhitung > Ftabel dimana Fhitung $=22,97$ dan Ftabel $=3,12$. Dengan demikian HO ditolak artinya adanya perbedaan penambahan konsentrasi pewarna alami bubuk ekstrak biji buah pinang terhadap rasa minuman sirup.

Hasil dari uji organoleptik menunjukkan bahwa bubuk ekstrak biji buah pinang layak digunakan sebagai pewarna alami pada produk minuman dengan tingkat warna, aroma dan rasa yang disukai pada konsentrasi 1 gram dalam $200 \mathrm{~mL}$ air atau 0,005 g/mL pewarna.

\section{KESIMPULAN}

Berdasarkan hasil yang diperoleh disimpulkan bahwa identifikasi zat warna alami yang terdapat dalam biji buah pinang mengandung tanin dan antosianin. Zat warna alami biji buah pinang stabil pada $\mathrm{pH} 6$ dengan pemanasan pada suhu $40^{\circ} \mathrm{C}$ dan disimpan selama 2 hari. Warna, aroma dan rasa disukai pada konsentrasi $0,005 \mathrm{~g} / \mathrm{mL}$ pewarna.

\section{DAFTAR PUSTAKA}

Arifah, C. N., Saleh, C., \& Erwin -. (2016). Uji Fitokimia Dan Uji Stabilitas Zat Warna Dari Ekstrak Biji Buah Alpukat (Persea americana Mill) Dengan Metode Spektroskopi UV-VIS. JURNAL ATOMIK, 1(1), 18-22.

Azizah, E., \& Hartana, A. (2018). Pemanfaatan Daun Harendong (Melastoma malabathricum) Sebagai Pewarna Alami Untuk Kain Katun. Dinamika Kerajinan Dan Batik, 35(1), 1-8.

Chintya, N., \& Utami, B. (2017). Ekstraksi Tannin dari Daun Sirsak (Annona muricata L.) sebagai Pewarna Alami Tekstil. JC-T (Journal Cis-Trans): Jurnal Kimia Dan Terapannya, 1(1), 22-29. https://doi.org/10.17977/um026v1i12017p 022

Fauziah, N. A., Saleh, C., \& Erwin -. (2016). Ekstraksi Dan Uji Stabilitas Zat Warna Dari Kulit Buah Alpukat (Persea americana Mill)
Dengan Metode Spektroskopi UV-VIS. JURNAL ATOMIK, 1(1), 23-27.

Giusti, M. M., \& Wrolstad, R. E. (2001). Characterization and Measurement of Anthocyanins by UV-Visible Spectroscopy. Current Protocols in Food Analytical Chemistry, 00(1), F1.2.1F1.2.13.

https://doi.org/10.1002/0471142913.faf01 02s00

Imelda, F. (2006). Optimasi Metode Penentuan Tanin (Analisis Tanin secara Spektrofotometri dengan Pereaksi OrtoFenantrolin). Kaunia Jurnal Sains Dan Teknologi, 2(2), 107-120.

Mahfud, T. (2015). Ekstraksi Pewarna Alami Kelopak Bunga Rosella (Hisbiscus sabdariffa) Pada Pembuatan Minuman Serbuk Instan Rosella. JST (Jurnal Sains Terapan), 1(1), Article 1. https://doi.org/10.32487/jst.v1i1.29

Marliana, S., Suryanti, V., \& Suyono. (2005). Skrining Fitokimia dan Analisis Kromatografi Lapis Tipis Komponen Kimia Buah Labu Siam (Sehium edule J.) dalam Ekstrak Etanol. Biofarmasi, 3(1), 26-31.

Mukhriani, M., Nonci, F. Y., \& Mumang, M. (2014). Penetapan Kadar Tanin Total Ekstrak Biji Jintan Hitam (Nigella sativa) Secara Spektrofotometri UV-VIS. Jurnal farmasi UIN Alauddin Makassar, 2(4), 154-158. https://doi.org/10.24252/jurfar.v2i4.2162

Neliyanti, \& Idiawati, N. (2014). Ekstraksi Dan Uji Stabilitas Zat Warna Alami Dari Buah Lakum (Cayratia trifolia (L.) Domin). Jurnal Kimia Khatulistiwa, 3(2), 86-93.

Nurandriea, E., \& Azmi, D. (2017). Ekstraksi Zat Warna Alami Dari Kayu Secang (Caesalpinia Sappan Linn) Dengan Metode Ultrasound Assisted Extraction Untuk Aplikasi Produk Pangan. [Skripsi]. ITS, Surabaya.

Pujilestari, T. (2015). Review: Sumber dan Pemanfaatan Zat Warna Alam untuk Keperluan Industri. Dinamika Kerajinan dan Batik: Majalah IImiah, 32(2), 93-106. https://doi.org/10.22322/dkb.v32i2.1365

Seafast. (2012). Pewarna Alami untuk Pangan. SEAFAST Center Research and Community Service Institution IPB.

Suarsa, I. W., Suarya, P., \& Kurniawati, I. (2011). Optimasi Jenis Pelarut Dalam Ekstraksi Zat Warna Alam Dari Batang Pisang Kepok (Musa paradiasiaca L. cv 
kepok) Dan Batang Pisang Susu (Musa paradiasiaca L. cv susu). Jurnal Kimia (Journal of Chemistry), 10(1), 59-63.

Sulastry, T. (2009). Analisis Kadar Tanin Ekstrak Air dan Ekstrak Etanol pada Biji Pinang Sirih (Areca catechu. L). Chemica: Jurnal IImiah Kimia Dan Pendidikan Kimia, 10(1),

59-63. https://doi.org/10.35580/chemica.v10i1.40 1

Wulansari, A., Prasetyo, D. B., Lejaringtyas, M., Hidayat, A., \& Anggarini, S. (2012). Aplikasi dan Analisis Kelayakan Pewarna Bubuk Merah Alami Berantioksidan dari Ekstrak Biji Buah Pinang (Areca catechu) sebagai Bahan Pengganti Pewarna Sintetik pada Produk Pangan. Industria: Jurnal Teknologi dan Manajemen Agroindustri, 1(1), 1-9. 